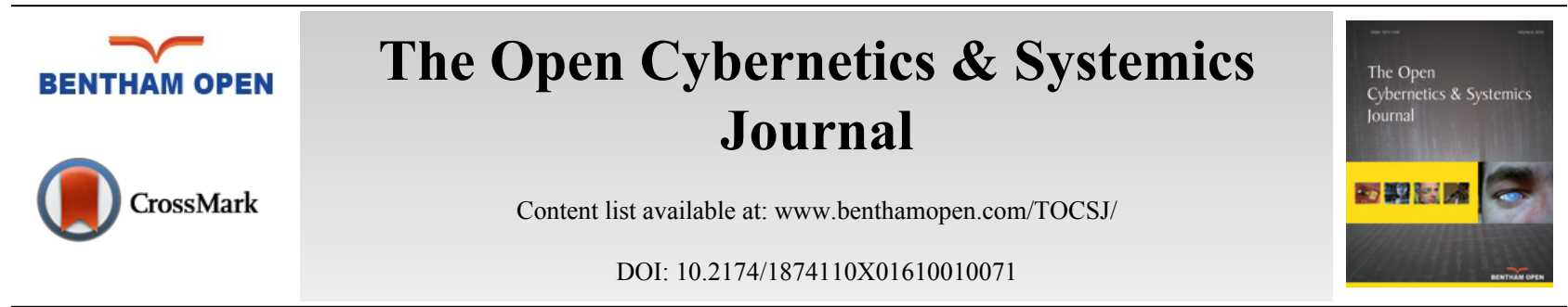

\title{
Retraction Notice: Green Construction Economy Research Based on LCC Theory
}

Zhenlin Yan ${ }^{*}$

Department of Engineering Economics, Henan College of Finance \& Taxation, Zhengzhou, Henan, 451464, China

\section{RETRACTION}

The Publisher and Editor have retracted this article [1] in accordance with good ethical practices. After thorough investigations we believe that the peer review process was compromised. The article was published online on 02-11-2015.

\section{REFERENCE}

[1] Z. Yan, "Green Construction Economy Research Based on LCC Theory", Open Cybern. Syst. J., vol. 9, pp. 2805-2810, 2015.

This is an open access article licensed under the terms of the Creative Commons Attribution-Non-Commercial 4.0 International Public License (CC BY-NC 4.0) (https://creativecommons.org/licenses/by-nc/4.0/legalcode), which permits unrestricted, non-commercial use, distribution and reproduction in any medium, provided the work is properly cited.

* Address correspondence to this author at the Department of Engineering Economics, Henan College of Finance \& Taxation, Zhengzhou, Henan, 451464, China; Tel: 13598063005; E-mail: yanzl1997@126.com 